\title{
Moisture sorption isotherms of raw and extruded wholemeal sorghum flours studied by the dynamic and salt slurry methods
}

\author{
Isotermas de sorção de farinhas integrais cruas e extrudadas estudadas pelos \\ métodos dinâmico e de solução saturada
}

\section{Melicia Cintia Galdeano1, Renata Valeriano Tonon', Carlos Wanderlei Piler de Carvalho1* (1), Neuri Santos Menezes' ${ }^{1}$, Regina Isabel Nogueira', William Ferreira Leal-Junior', Adriana Paula Silva Minguita ${ }^{1}$}

1 Embrapa Agroindústria de Alimentos, Rio de Janeiro/RJ - Brasil

\section{*Corresponding Author:}

Carlos Wanderlei Piler de Carvalho, Embrapa Agroindústria de Alimentos, Av. das Américas, 29501, CEP: 23020-470, Rio de Janeiro/RJ - Brasil, e-mail: carlos.piler@embrapa.br

Cite as: Moisture sorption isotherms of raw and extruded wholemeal sorghum flours studied by the dynamic and salt slurry methods. Braz. J. Food Technol., v. 21, e2017207, 2018.

Received: Nov. 22, 2017; Accepted: Mar. 28, 2018

\section{Abstract}

The saturated salt slurry method has been a standard method for many years, but there are several drawbacks, including long equilibration times, extensive labour and mould growth at high water activity (aw) values. The validity of the dynamic method (automated sorption instrument) was investigated by comparing it with the equilibrium isotherms obtained using the saturated salt slurry method for two food materials (whole sorghum raw flour and whole grain sorghum extrudates), as well as their diffusion coefficients. The sorption isotherms ranged between $11.3 \%$ and $84.3 \%$. The equilibration time for the highest water activity (0.843) was about 30 days using the saturated salts method, considerably longer than using the dynamic method (300 min). For raw sorghum flour, the dynamic method values were consistent with the data obtained using the traditional method, which can be confirmed by the similar curves and monolayer values obtained $(0.038$ and $0.040 \mathrm{~g}$ water $/ \mathrm{g}$ solids for the salt slurry and dynamic methods, respectively). For the sorghum extrudates, the equilibrium moisture values were higher using the dynamic method, which could be related to the low diffusion coefficient of the material (order of 10-10). The authors suggest the use of the dynamic method as a better alternative to the saturated salt method in order to determine the sorption isotherms of whole grain sorghum-based food materials.

Keywords: Automated sorption instrument; Cereal flour storage; Diffusion coefficient; Thermoplastic extrusion; Sorption isotherm; Moisture equilibrium.

\section{Resumo}

O método de solução saturada tem sido um método padrão por muitos anos, mas existem várias desvantagens, incluindo longos períodos de equilíbrio, trabalho extensivo e crescimento de fungo em valores altos de atividade de água (aw). Foi investigada a validade do método dinâmico (instrumento de sorção automatizado), comparando-o às isotermas de equilíbrio solução saturada de dois alimentos (farinha crua e processada por extrusão de sorgo inteiro), bem como seus coeficientes de difusão. As isotermas de sorção variaram entre $11,3 \%$ e $84,3 \%$. O tempo de equilíbrio para a maior atividade de água $(0,843)$ foi de cerca de 30 dias para o método de solução saturada, consideravelmente mais longo que o método dinâmico (300 min). Para a farinha de sorgo crua, os valores do método dinâmico foram consistentes com os dados obtidos a partir do método tradicional, que podem ser confirmados pelas curvas e pelos valores monocamadas semelhantes $(0,038$ e 0,040 g de sólidos de água/g, para suspensão de sal e métodos dinâmicos, respectivamente). Para a farinha de extrudados de sorgo, os valores de umidade de equilíbrio foram maiores usando o método dinâmico, o que pode estar relacionado ao baixo coeficiente de difusão do material (ordem para 10-10). Sugere-se o uso de um método dinâmico como uma melhor alternativa ao método da solução saturada, a fim de determinar as isotermas de sorção de materiais alimentares à base de sorgo integral.

Palavras-chave: Instrumento de sorção automatizado; Armazenamento de farinhas de cereais; Coeficiente de difusão; Extrusão termoplástica; Isoterma de sorção; Equilíbrio de umidade. 


\section{Introduction}

The relationship between the water activity (aw) and moisture content of a material at a given temperature is called the moisture sorption isotherm. This relationship is complex and unique for each product. Sorption isotherms are sigmoidal in shape for most foods, although isotherm curves of foods that contain large amounts of sugar have a J-type shape (FENNEMA, 1996). Sorption isotherms can be divided into three zones. Zone I (aw < 0.25) represents the monolayer water, which is strongly associated with the food material, unable to freeze and not easily removed by drying. Zone II $(0.25<$ aw $<0.75)$ represents the water that is adsorbed or absorbed in multilayers within foods and solutions of soluble components. It is slightly less mobile than bulk water. As water is added at the low-moisture end of this region, it exerts a significant plasticizing action on the solutes, lowering their glass transition temperatures and causing swelling of the solid matrix. Zone III (aw > 0.75) represents the "free" water, which is freezable and easily removed by drying. This water is available for microbial growth and enzymatic activity (FENNEMA, 1996).

The methods used to determine sorption isotherms can be divided into static and dynamic techniques. The static gravimetric method, also called the traditional method, is described in both the European (ISO, 2013) and American (ASTM, 2010) standards (GARBALIŃSKA et al., 2017). In this method, dried (desorption), hydrated (adsorption) or native (working) samples are placed in closed chambers (desiccators) where saturated salt slurries provide different relative humidity $(\mathrm{RH})$ values at constant temperature. The mass is weighed at specific intervals until equilibrium is achieved (LABUZA; ALTUNAKAR, 2007; GARBALIŃSKA et al., 2017). Since each saturated salt slurry provides only one $\mathrm{RH}$ value, different $\mathrm{RH}$ values are obtained by choosing a series of salts. When a material is placed in a desiccator, it gains or loses moisture until reaching equilibrium with the saturated slurry, and after this time no further weight change is observed. The moisture content, calculated based on the final sample weight, is referred to as the equilibrium moisture content (PENNER, 2013).

This method has the advantage of producing good results as well as allowing many samples to be measured simultaneously at low cost (PENNER, 2013). However, it presents some limitations, such as: 1) long period of time to reach equilibrium, 2) great variation in the measurements due to the need to frequently remove samples from the chambers for weighing, 3) conditions inside the desiccators are disrupted by the periodic openings to take measurements, and 4) mould growth may occur on samples at high $\mathrm{RH}$ values during long equilibration times (LEWICKI; POMARANSKA-LAZUKA, 2003; BOHN et al., 2005).

Thus the dynamic method could overcome the disadvantages found in the saturated salt slurry method.
Relatively new in the food industry, dynamic systems have been used in the pharmaceutical industry since their introduction in 1994. Commercially available equipment for dynamic analysis include the Dynamic Vapour Sorption (DVS) (Surface Measurement Systems Ltd., UK), the SGA-100 Symmetric Gravimetric Analyser (VTI Corporation, USA), the Cisorp Water Sorption Analyser (C.I. Electronics Ltd., UK), the Q5000SA Sorption Analyser (TA Instruments, USA) and the AquaSorp (Decagon Devices, USA) (TEOH et al., 2001; YU et al., 2008). However, the data from the latter instrument cannot be compared with the water sorption from the conventional water sorption method because its principle includes the generation of an airflow that continuously passes over the sample for a determined time, resulting in controllable changes of water activity (NURHADI; ROOS, 2016).

The dynamic analyses do not require the use of saturated salt solutions in order to provide the desired $\mathrm{RH}$, but instead use mixtures of dry nitrogen and saturated water vapour, whose proportions are precisely controlled by mass flow controllers, to produce any desired water activity environment in the chamber. Due to the high precision and sensitivity, the automated instruments require very small amounts of sample. Thus, due to the sample size, small chamber and continuous flow of dry nitrogen and saturated water vapour mixture over the sample, equilibrium is reached faster, which avoids the risk of mould growth at high $\mathrm{RH}$. In addition, the instruments maintain the $\mathrm{RH}$ and temperature conditions of the material throughout the duration of the experiment. However, the best advantage of the instrumental methods is related to the time of analysis. The instruments provide faster results compared to the traditional technique, besides being less laborious (YU, 2007; YU et al., 2008; BINGOL et al., 2012; PENNER, 2013).

Although the use of automated sorption instruments is becoming standard practice in many industries, there are few studies comparing the traditional salt slurry and dynamic methods (TEOH et al., 2001; ARLABOSSE et al., 2003; YU, 2007; BINGOL et al., 2012). Therefore, considering the above-mentioned advantages of the instrumental method over the traditional one and the lack of studies in the literature comparing both methods to obtain sorption isotherms for different materials, the aim of this study was to compare the salt slurry and dynamic methods to obtain sorption isotherms for two whole grain sorghum-based food materials.

\section{Materials and methods}

\subsection{Materials}

Two materials were selected for use in this study: raw sorghum flour (92.33 $\mu \mathrm{m})$ and sorghum extrudates (3.43 $\pm 0.49 \mathrm{~mm}$ diameter). Sorghum grains (genotype SC319), provided by Embrapa Milho e Sorgo (Sete Lagoas, $M G)$, were ground using a model LM3600 disc mill 
(Perten Instruments AB, Huddinge, Sweden), resulting in raw whole grain sorghum flour. The raw whole grain sorghum flour was extruded in a model Evolum HT 25 co-rotating twin-screw extruder (Clextral, Firminy, France). The screw speed (600 rpm), moisture content (14\%) and temperature profile $\left(30,30,60,90,100,100,120,120,150\right.$ and $\left.150{ }^{\circ} \mathrm{C}\right)$ were maintained constant and the die had four holes, each $3.8 \mathrm{~mm}$ in diameter. The extrudates were collected, placed in trays and dried in a fan oven at $60^{\circ} \mathrm{C}$ for $4 \mathrm{~h}$. After drying, they were stored in plastic bags at $25^{\circ} \mathrm{C}\left( \pm 2{ }^{\circ} \mathrm{C}\right)$ until further analysis.

\subsection{Sorption isotherms}

\subsubsection{Traditional saturated salt slurry method}

The sorption isotherms were first determined by the gravimetric method according to $\mathrm{Yu}$ (2007). Eight saturated salt slurries were prepared at $60{ }^{\circ} \mathrm{C}\left(\mathrm{LiCl}, \mathrm{CH}_{3} \mathrm{COOK}\right.$, $\mathrm{MgCl}_{2}, \mathrm{~K}_{2} \mathrm{CO}_{3}, \mathrm{Mg}\left(\mathrm{NO}_{3}\right)_{2}, \mathrm{KI}, \mathrm{NaCl}$ and $\mathrm{KCl}$ ) according to Nyqvist (1983), in order to provide relative humidity values of $11.3 \%, 22.6 \%, 32.8 \%, 43.2 \%, 52.9 \%, 68.9 \%, 75.3 \%$ and $84.3 \%$, respectively (GREENSPAN, 1977). All the salts were acquired from Sigma-Aldrich and the water activity of each saturated solution was verified at $25^{\circ} \mathrm{C}$ using the AquaLab Lite equipment (Decagon, Pullman, USA). Prior to analysis, the samples were dried in a desiccator with anhydrous calcium chloride for 20 days according to Galdeano et al. (2009). Triplicate $1 \mathrm{~g}$ samples were equilibrated over the saturated slurries in $2.4 \mathrm{~L}$ borosilicate glass desiccators with $160 \mathrm{~mm}$ diameters placed in controlled temperature model HY350U BOD incubators (Hydrosan, Belo Horizonte, MG) at $25 \pm 2{ }^{\circ} \mathrm{C}$. Each sample was weighed on a model AUX 320 balance (Shimadzu, Tokyo, Japan) at regular intervals for seven days until equilibrium was achieved, which was considered to be when the change in sample weight did not exceed $0.1 \%$. The equilibrium moisture content was calculated from the increase in mass of the samples after equilibration at a given $\mathrm{RH}$, following the methodology described by Ascheri et al. (2006). The data were also fitted to the modified BET model as described below.

\subsubsection{Dynamic method}

The experiments were carried out using a Q5000SA Sorption Analyser (TA Instruments, New Castle, USA), equipped with a high-accuracy microbalance $(0.1 \mathrm{mg} \pm 1 \%)$. The accuracy of the system was $\pm 1 \%$ for the $\mathrm{RH}$ over a range from 0 to $98 \%$ and $\pm 0.1^{\circ} \mathrm{C}$ for the temperature stability. To take a measurement, the samples (3 to $5 \mathrm{mg}$ ) were first dried in the instrument at $60^{\circ} \mathrm{C}$ and $0 \% \mathrm{RH}$, and then subjected to the same $\mathrm{RH}$ values used in the traditional method (11.3, 22.6, 32.8, 43.2, 52.9, 68.9, 75.3 and 84.3\%). The $\mathrm{RH}$ was increased step by step during adsorption and the samples were maintained at each humidity level until no further weight change was detected. The time required to reach equilibrium moisture varied for each $\mathrm{RH}$ and each material. The mass of the sample was determined continuously during the test. All experiments were carried out in triplicate at $25^{\circ} \mathrm{C}$ with a total gas flow of $200 \mathrm{~mL} / \mathrm{min}$ and the data were also fitted to the modified BET model as described below.

\subsubsection{Mathematical modelling}

One of the equations most widely used to describe sorption isotherms is that of the Brunauer-Emmett-Teller (BET) model (Equation 1), since it has a theoretical background and the parameters provide a physical meaning related to the sorption process, different from the empirical models. The BET model is considered to be an effective method for estimating the amount of bound water at specific polar sites in dehydrated food systems (SAHIN; GÜLÜM, 2006).

$$
X_{e}=\frac{X_{m} C_{B E T} a_{w}}{\left(1-a_{w}\right)\left(1-a_{w}+C_{B E T} a_{w}\right)}
$$

However, the BET model is not adequate for water activities above 0.5 (JONQUIĖRES; FANE, 1998; GOULA et al., 2008), and is unable to accurately predict the sorption behaviour in such cases (Equation 1). In their original publication, Brunauer et al. (1938) derived a modified model with three parameters, considering a limited number of adsorbed layers, which allowed for the modelling with water activities of up to 0.9 (Equation 2).

$$
X_{e}=\frac{X_{m} C_{B E T} a_{w}\left[1-(n+1)\left(a_{w}\right)^{n}+n\left(a_{w}\right)^{n+1}\right]}{\left(1-a_{w}\right)\left[1+\left(C_{B E T}-1\right) a_{w}-C_{B E T}\left(a_{w}\right)^{n+1}\right]}
$$

Where: $X_{e}$ is the equilibrium moisture content at a given water activity $\left(a_{w}\right), X_{m}$ is the monolayer value (g water/g solids) and $C_{B E T}$ and $n$ are model constants.

Thus, in the present work, the sorption isotherms data were modelled according to the modified BET model (Equation 2), using the Solver algorithm of Microsoft Excel (Microsoft, Redmond, USA).

\subsubsection{Diffusion coefficient}

The effective diffusion coefficients $\left(D_{\text {eff }}\right)$ of water into raw sorghum flour and into sorghum extrudates were determined according to Fick's second law, applied to an infinite slab and to a sphere, respectively. The analytical solutions of the diffusion equation for these two cases, as described by Crank (1979), are expressed by Equations 3 and 4 .

$$
\begin{aligned}
& \left(\frac{X_{t}-X_{e}}{X_{0}-X_{e}}\right)=\frac{8}{\pi^{2}} \sum_{n=1}^{\infty} \frac{1}{(2 n-1)^{2}} \exp \left[-(2 n-1)^{2} \frac{\pi^{2} D_{\text {eff }} t}{L^{2}}\right] \\
& \left(\frac{X_{t}-X_{e}}{X_{0}-X_{e}}\right)=\frac{6}{\pi^{2}} \sum_{n=1}^{\infty} \frac{1}{n^{2}} \exp \left[-n^{2} \frac{\pi^{2} D_{\text {eff }} t}{r^{2}}\right]
\end{aligned}
$$


Where: $X_{t}=$ the moisture content at time $t, X_{0}=$ the initial moisture content, $X_{e}=$ the equilibrium moisture content, $D_{\text {eff }}=$ effective diffusion coefficient for water $\left(\mathrm{m}^{2} \mathrm{~s}^{-1}\right)$, $L=$ thickness of the sorghum flour layer $(m), r=$ extrudate radius and $n=$ number of terms in the series.

Eighteen terms were used to determine the moisture diffusivity ( $n=18)$ and "shrinkage" of the monolayer was neglected, i.e., $L$ and $r$ were considered constant $(\mathrm{L}=0.001 \mathrm{~m}$ and $r=0.0017 \mathrm{~m})$ throughout the sorption isotherms determination.

\section{Results and discussion}

\subsection{Moisture equilibration time}

Water adsorption is characterized by an increase in sample mass after changing the $\mathrm{RH}$ conditions, tending to reach a constant value (equilibration conditions) after a certain time (ROMAN-GUTIERREZ et al., 2002). In the present study, the time needed to reach these apparent equilibration conditions (plateau) using the automated instrumental method ranged, for each $\mathrm{RH}$, from 120 to 210 min for the raw flour and from 130 to 300 min for the extrudates (Figure 1). The equilibration time for the highest water activity (0.84) was about 30 days for the saturated salts method, considerably longer than for the dynamic method at the same $\mathrm{RH}$ (300 min).
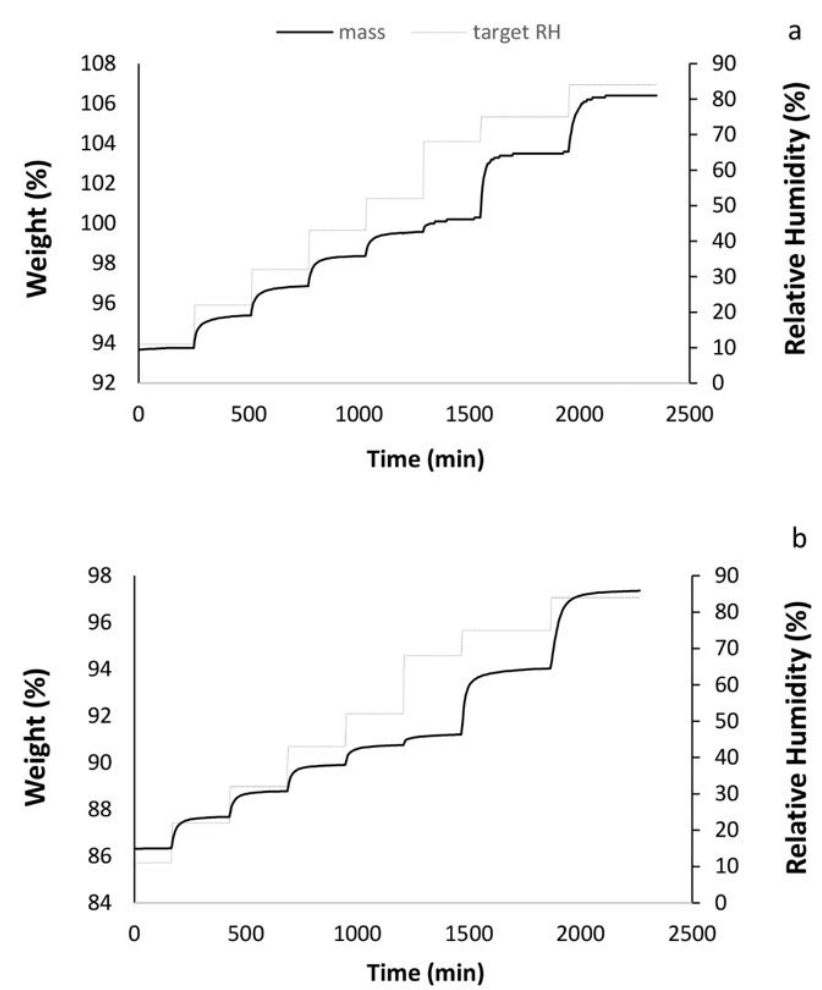

b

Figure 1. Time to reach the equilibrium moisture content at different $\mathrm{RH}$ levels for (a) raw sorghum flour and (b) sorghum extrudates.
Compared to the weeks of equilibration time reported in the literature for the static method for most foods, the automated sorption instrument has the advantage of reaching the equilibrium conditions much quicker. These low equilibration times could be associated with the very small sample sizes ( 3 to $5 \mathrm{mg}$ ) and the continuous flow of nitrogen and water vapour mixture over the product. In the present work, eight $\mathrm{RH}$ levels were used, and the time required to obtain the complete sorption isotherm was approximately two days. Similar equilibration time ranges were reported in other studies for rice grains and wheat flour (ROMAN-GUTIERREZ et al., 2002; BINGOL et al., 2012).

These rapid equilibration times also have the advantage of obtaining isothermal points at high water activities without concern about microbial degradation, as well as the increase in isothermal modelling accuracy at higher relative humidity values (BOHN et al., 2005).

\subsection{Sorption isotherms}

Figure 2 shows the raw sorghum flour and sorghum extrudates sorption isotherms obtained by the traditional and dynamic methods, while the BET model parameters are shown in Table 1.
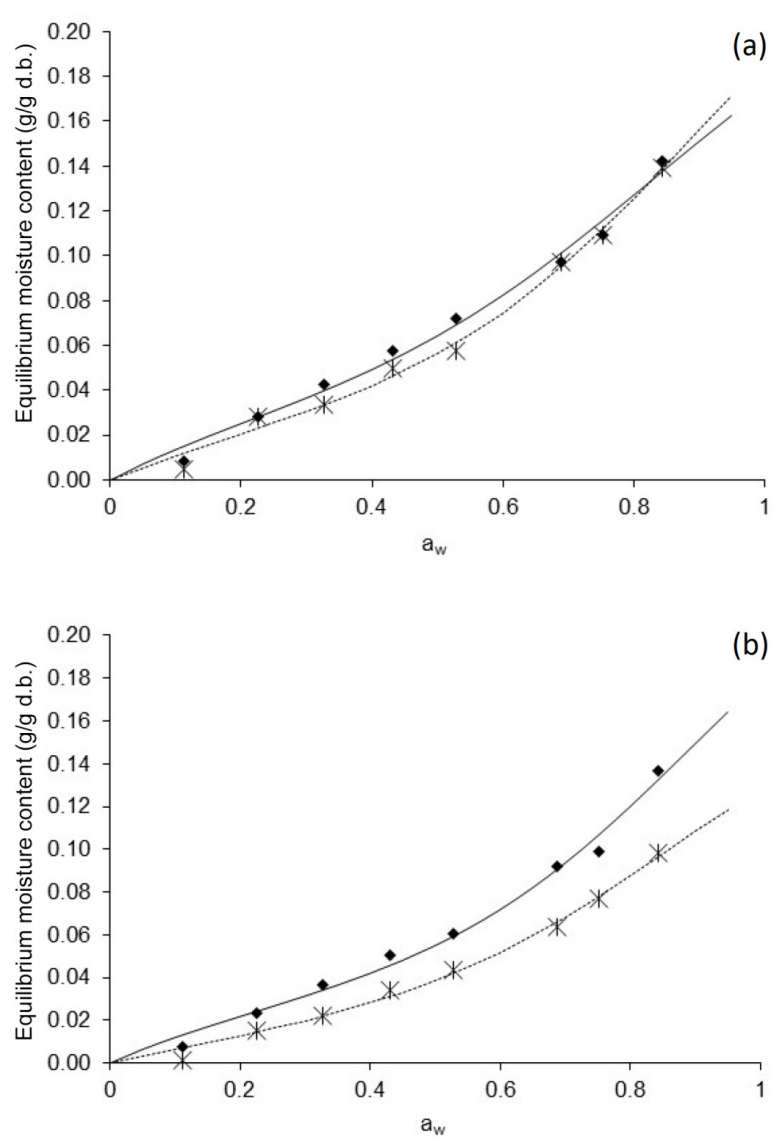

Figure 2. Sorption isotherms for raw sorghum flour (a) and sorghum extrudates (b). The lines were derived from the BET model. (a) Salt slurry and (b) dynamic methods. 
Moisture sorption isotherms of raw and extruded wholemeal sorghum flours studied by the dynamic and salt slurry methods Galdeano, M. C. et al.

Table 1. Estimated BET parameters for the raw sorghum flour and sorghum extrudates using the saturated salt slurries and dynamic methods of analysis.

\begin{tabular}{cccccc}
\multirow{2}{*}{ Product } & Method & \multicolumn{3}{c}{ BET parameters } \\
\cline { 3 - 6 } & & $\mathbf{X}_{\mathbf{m}}$ & $\mathbf{C}$ & $\mathbf{n}$ & $\mathbf{R}^{2}$ \\
\multirow{2}{*}{ Raw sorghum flour } & Salt slurry & 0.038 & 3.199 & 8.589 & 0.993 \\
\multirow{2}{*}{ Sorghum extrudates } & Dynamic & 0.040 & 3.813 & 7.679 & 0.989 \\
& Salt slurry & 0.028 & 2.293 & 9.279 & 0.993 \\
\hline
\end{tabular}

$\mathrm{X}_{m}=$ monolayer value ( $\mathrm{g}$ water/g solids); $\mathrm{C}$ and $\mathrm{n}$ are BET constants.

Table 2. Effective diffusion coefficients (Deff) of water into raw sorghum flour and sorghum extrudates at different water activities (aw).

\begin{tabular}{cccc} 
Product & \multicolumn{3}{c}{$\mathbf{D}_{\text {eff }}\left(\mathbf{m}^{\mathbf{2}} \mathbf{s}^{-1}\right)$} \\
\cline { 2 - 4 } & $\mathbf{a w ~} \mathbf{0 . 2 2 6}$ & $\mathbf{a w} \mathbf{0 . 5 2 9}$ & $\mathbf{a w ~ \mathbf { 0 . 8 4 3 }}$ \\
Raw sorghum flour & $1.6 \times 10^{-10}$ & $1.5 \times 10^{-10}$ & $1.6 \times 10^{-10}$ \\
Sorghum extrudates & $7.3 \times 10^{-10}$ & $5.1 \times 10^{-10}$ & $6.4 \times 10^{-10}$ \\
\hline
\end{tabular}

According to the Brunauer classification (BRUNAUER et al., 1938), the sorption isotherms exhibited a type II sigmoid shape. Type II isotherms represent the sigmoidal curve that describes the majority of processed foods, since they are typical of intermediate moisture materials.

For raw sorghum flour, the dynamic method values were consistent with the data obtained using the traditional method, which can be confirmed by the similar curves observed in Figure 2a. The agreement between the methods was good for the whole range of water activity, as also observed by Arlabosse et al. (2003).

Using the static method, the raw flour showed a moisture content of $0.140 \mathrm{~g}$ of water $/ \mathrm{g}$ of dry matter when submitted to a $\mathrm{RH}$ of $84.3 \%$, and $0.143 \mathrm{~g}$ of water $/ \mathrm{g}$ of dry matter using the dynamic method (data not shown). The BET equation yielded similar monolayer values $\left(X_{m}\right)$ when comparing the results obtained using the two methods of analysis (Table 1). The BET model is based on the monolayer moisture concept and provides the value for the monolayer moisture content of the material $\left(X_{m}\right)$ which is considered safe for dried foods during storage, whereas most other models fail to provide this parameter. The monolayer moisture content $\left(X_{m}\right)$ indicates the water that is strongly adsorbed to specific sites on the food surface, and is considered to be an important value to guarantee food stability. In order to maintain the food microbiologically safe during storage, based on the static method the raw sorghum flour should not contain more than $3.8 \mathrm{~g}$ of water $/ \mathrm{g}$ of dry matter, whereas for the sorghum extrudates this value should be even lower, $2.8 \mathrm{~g}$ of water $/ \mathrm{g}$ of dry matter. The Xm values varied from 0.028 to $0.040 \mathrm{~g}$ water/g solids, similar to the values observed by Tonon et al. (2009) and Purohit and Rao (2017).
For sorghum extrudates, the equilibrium moisture values obtained at all $\mathrm{RH}$ values were higher when using the dynamic method. The reproducibility between the two experimental methods was only good for water activities below 0.2 . For higher activity values, a significant difference appeared. Teoh et al. (2001) observed similar behaviour for the sorption isotherms of extruded cornmeal; there was a difference between the curves for all the $\mathrm{RH}$ values studied and the dynamic method showed higher equilibrium moisture content values.

The similarities and differences observed between the methods could be explained by the diffusion coefficient of the material (ARLABOSSE et al., 2003). According to these authors, when the diffusion coefficient is low $\left(<10^{-9} \mathrm{~m}^{2} \mathrm{~s}^{-1}\right)$, thermodynamic equilibrium is difficult to reach using the saturated salts method. However, if the apparent diffusion coefficient is above $10^{-9} \mathrm{~m}^{2} \mathrm{~s}^{-1}$, internal diffusion is not limiting enough to induce a discrepancy between the static and dynamic methods. Thus a comparison between the static and dynamic methods shows consistent results as long as the diffusion coefficient of the material is high. Hence the effective diffusion coefficients $\left(D_{\text {eff }}\right)$ of water into the sorghum flour and into the sorghum extrudates were calculated for three water activities $(0.226,0.529$ and 0.843$)$ and the results are shown in Table 2.

The estimated diffusion coefficients for the extrudates were $7.3,5.1$ and $6.4 \times 10^{-10} \mathrm{~m}^{2} \mathrm{~s}^{-1}$ for water activities of $0.226,0.529$ and 0.849 , respectively. Thus when comparing the methods, the difference found for the extrudates could be related to the low diffusion coefficient of the material. Since the diffusion coefficients were low (order of $10^{-10}$ ) in the present study, the use of a dynamic method to determine the sorption isotherms is suggested as a better alternative to the saturated salt method. 
Moisture sorption isotherms of raw and extruded wholemeal sorghum flours studied by the dynamic and salt slurry methods Galdeano, M. C. et al.

Using the static method, the extrudates presented a moisture content of $0.098 \mathrm{~g}$ of water $/ \mathrm{g}$ of dry matter when submitted to a $\mathrm{RH}$ of $84 \%$, whereas using the dynamic method it increased to $0.137 \mathrm{~g}$ of water $/ \mathrm{g}$ of dry matter under the same $\mathrm{RH}$ value (data not shown). Figure $2 \mathrm{~b}$ shows greater hygroscopicity for the sorghum extrudate evaluated by the dynamic method, as compared to the salt slurry method, which is in agreement with the higher monolayer values calculated by the BET model (Table 1).

For both samples, considering the time required to determine the complete sorption isotherm, equilibrium was reached after 30 days using the saturated salts method and around 30 hours when using the dynamic method it took.

\section{Conclusion}

The time required to reach the apparent equilibration conditions using the dynamic method was considerably lower than when using the salt slurry method. As a result, a sorption isotherm could be obtained in a few days using the automated sorption instrument, as compared to weeks using the saturated salts method. A comparison between the methods showed consistent results for the raw flour but some differences for the extrudates. The choice of one or the other method to determine the sorption isotherm is not easy. The saturated salts method involves low investment costs and is easy to implement, but the equilibrium criterion is difficult to define and the delay in equilibration can be very long. Using the dynamic method, the experimental time to produce a complete isotherm is much shorter, but the apparatus is expensive and requires some training in order to operate it, besides needing frequent maintenance. Thus a careful analysis should be carried before choosing the method, considering costs, available time and frequency of use.

\section{References}

ARLABOSSE, P.; RODIER, E.; FERRASSE, J. H.; CHAVEZ, S.; LECOMTE, D. Comparison between static and dynamic methods for sorption isotherm measurements. Drying Technology, v. 21, n. 3, p. 479-497, 2003. http://dx.doi.org/10.1081/DRT-120018458.

ASCHERI, D. P. R.; ANDRADE, C. T.; CARVALHO, C. W. P.; ASCHERI, J. L. R. Efeito da extrusão sobre a adsorção de água de farinhas mistas pré-gelatinizadas de arroz e bagaço de jabuticaba. Ciência e Tecnologia de Alimentos, v. 26, n. 2, p. 325-335, 2006. http://dx.doi.org/10.1590/S0101-20612006000200015.

ASTM INTERNATIONAL - ASTM. ASTM C1498-04a: standard test method for hygroscopic sorption isotherms of building materials. Philadelphia, 2010. 3 p.

BINGOL, G.; PRAKASH, B.; PAN, Z. Dynamic vapor sorption isotherms of medium grain rice varieties. LebensmittelWissenschaft + Technologie, v. 48, n. 2, p. 156-163, 2012. http://dx.doi.org/10.1016/j.Iwt.2012.02.026.
BOHN, D. M.; CADWALLADER, K. R.; SCHMIDT, S. J. Development and validation of a dynamic vapor sorption-fast gas chromatography-flame ionization detection method for rapid analysis of volatile release from glassy matrices. Journal of Agricultural and Food Chemistry, v. 53, n. 8, p. 3149-3155, 2005. http://dx.doi.org/10.1021/jf0487598. PMid:15826072.

BRUNAUER, S.; EMMETT, P. H.; TELLER, E. Adsorption of gases in multimolecular layers. Journal of the American Chemical Society, v. 60, n. 2, p. 309-319, 1938. http://dx.doi.org/10.1021/ ja01269a023.

CRANK, J. The mathematics of diffusion. Oxford: Oxford University Press, 1979. p. 415.

FENNEMA, O. R. Food chemistry. 3rd ed. New York: Marcel Dekker, 1996.

GALDEANO, M. C.; MALI, S.; GROSSMANN, M. V. E.; YAMASHITA, F.; GARCÍA, M. A. Effects of plasticizers on the properties of oat starch films. Materials Science and Engineering C, v. 29, n. 2, p. 532-538, 2009. http://dx.doi.org/10.1016/j.msec.2008.09.034.

GARBALI SKA, H.; BOCHENEK, M.; MALORNY, W.; VON WERDER, J. Comparative analysis of the dynamic vapor sorption (DVS) technique and the traditional method for sorption isotherms determination - Exemplified at autoclaved aerated concrete samples of four density classes. Cement and Concrete Research, v. 91, p. 97-105, 2017. Supplement C.

GOULA, A. M.; KARAPANTSIOS, T. D.; ACHILIAS, D. S.; ADAMOPOULOS, K. G. Water sorption isotherms and glass transition temperature of spray dried tomato pulp. Journal of Food Engineering, v. 85, n. 1, p. 73-83, 2008. http://dx.doi. org/10.1016/j.jfoodeng.2007.07.015.

GREENSPAN, L. Humidity fixed points of binary saturated aqueous solutions. Journal of Research of the National Bureau of Standards, v. 81, n. 1, p. 89-96, 1977. http://dx.doi.org/10.6028/ jres.081A.011.

INTERNATIONAL ORGANIZATION FOR STANDARDIZATION ISO. ISO 12571: hydrothermal performance of building materials and products: determination of hygroscopic sorption properties. Geneva, 2013.

JONQUIÈRES, A.; FANE, A. Modified BET models for modeling water vapor sorption in hydrophilic glassy polymers and systems deviating strongly from ideality. Journal of Applied Polymer Science, v. 67, n. 8, p. 1415-1430, 1998. http://dx.doi.org/10.1002/ (SICI)1097-4628(19980222)67:8<1415::AID-APP7>3.0.CO;2-H.

LABUZA, T. P.; ALTUNAKAR, B. Water activity prediction and moisture sorption isotherms. In: BARBOSA-CÁNOVAS, G. V; FONTANA, A. J.; SCHMIDT, S. J.; LABUZA, T. P. (Ed.). Water activity in foods: fundamentals and applications. Oxford: Blackwell Publishing, 2007. p. 109-154 http://dx.doi.org/10.1002/9780470376454.ch5.

LEWICKI, P. P.; POMARANSKA LAZUKA, W. Errors in static desiccator method of water sorption isotherms estimation. 
Moisture sorption isotherms of raw and extruded wholemeal sorghum flours studied by the dynamic and salt slurry methods Galdeano, M. C. et al.

International Journal of Food Properties, v. 6, n. 3, p. 557-563, 2003. http://dx.doi.org/10.1081/JFP-120021335.

NURHADI, B.; ROOS, Y. H. Dynamic water sorption for the study of amorphous content of vacuum-dried honey powder. Powder Technology, v. 301, p. 981-988, 2016. https://doi.org/10.1016/j. powtec.2016.07.055.

NYQVIST, H. Saturated salt solutions for maintaining specified relative humidities. Journal of Pharmaceutic Technology and Production Manufacture, v. 4, n. 2, p. 47-48, 1983.

PENNER, E. A. Comparison of the new vapor sorption analyzer to the traditional saturated salt slurry method and the dynamic vapor sorption instrument. 2013. $119 \mathrm{f}$. Thesis (Master of Science in Food Science and Human Nutrition)--University of Illinois, Urbana-Champaign, 2013

PUROHIT, S. R.; RAO, P. S. Modelling and analysis of moisture sorption isotherm of raw and pregelatinized rice flour and its crystalline status prediction. Food Analytical Methods, v. 10, n. 6, p. 1914-1921, 2017.

ROMAN-GUTIERREZ, A. D.; GUILBERT, S.; CUQ, B. Distribution of water between wheat flour components: a dynamic water vapour adsorption study. Journal of Cereal Science, v. 36, n. 3, p. 347-355, 2002. http://dx.doi.org/10.1006/jcrs.2002.0470.
SAHIN, S.; GÜLÜM, S. Physical properties of foods. New York: Springer, 2006.

TEOH, H. M.; SCHMIDT, S. J.; DAY, G. A.; FALLER, J. F. Investigation of cornmeal components using dynamic vapor sorption and differential scanning calorimetry. Journal of Food Science, v. 66, n. 3, p. 434-440, 2001. http://dx.doi.org/10.1111/j.1365-2621.2001. tb16125.x.

TONON, R. V.; BARONI, A. F.; BRABET, C.; GIBERT, O.; PALLET, D.; HUBINGER, M. D. Water sorption and glass transition temperature of spray dried açai (Euterpe oleracea Mart.) juice. Journal of Food Engineering, v. 94, n. 3-4, p. 215-221, 2009. https://doi.org/10.1016/j.jfoodeng.2009.03.009.

$Y U, X$. Investigation of moisture sorption properties of food materials using saturated salt solution and humidity generating techniques. 2007. $262 \mathrm{f}$. Dissertation (Master of Science in Food Science and Human Nutrition)--University of Illinois, Urbana-Champaign, 2007.

YU, X.; SCHMIDT, A. R.; BELLO-PEREZ, L. A.; SCHMIDT, S. J. Determination of the bulk moisture diffusion coefficient for corn starch using an automated water sorption instrument. Journal of Agricultural and Food Chemistry, v. 56, n. 1, p. 50-58, 2008. http://dx.doi.org/10.1021/jf071894a. PMid:18078318. 